refugee community as an active community by providing better health facilities, especially as prevention of malnutrition and blindness is an input which requires minimum facilities and finances. They feel the international community could help in this.

Basic needs of housing could be provided by NGO's who are more than willing to step in. Drinking water, better sanitation and work opportunity are basic rights of the refugee. Dole should be increased according to inflationary tendencies. They feel change can come if members of government staff are trained in the process of refugee rehabilitation.

The above are the combined views put forward by refugee NGO's, TULF members in India and journalists interested in refugee work.

Some of them are important and part of a refugee's human rights. Others will frighten any asylum giving country as it denotes the refugees' attempts to remain. Through speaking to refugees, it was noticed that the refugees want to remain only temporarily. Policy makers do not believe this and the continuation of the crisis confirms their stand that the Sri Lankan refugee is to stay a long time.

The Indian policy towards the Sri Lankan refugees was magnanimous until the assassination of Rajiv Gandhi two years ago. As people forget the event the situation will normalize as it has already done in many camps. In the meantime, repatriation takes a back seat. So the Sri Lankan refugee remains a cornered humanity with few rights and fear of the future.

\section{References}

Mohandas, K. 1992. M.G.R.: The Man and the Myth. Bangalore: Panther Publishers.

Karunanidhi, M. 1990. Answers to Adversaries. Madras: D.M.K. Party

Thillai Rajah, N. 1989. “India's Brilliant Achievement In Sri Lanka". September 1,Vol. 2, No. 14. London: Tamil Voice International.

Public (Refugees Rehabilitation) Department, Policy Note. 1987. Miscellaneous Relief and Rehabilitation of Indians Overseas and Refugees and Evacuees: Demand Note No.43. Madras: Government of Tamil Nadu.

Varadakumar, V. 1992. Problem's and Prospects: Resettlement Services for People Affected by Violence in the Tamil Homeland, Sri Lanka, Visit Report. London: Tamil Information Centre.

\title{
Only Man Is Vile: The Tragedy of Sri Lanka
}

\author{
by William McGowan \\ New York: Farrar, Straus and Giroux, 1992. 382. \\ Reviewed by Ravindiran Vaitheespara
}

This is a book that is difficult to categorize. It is, in part, a travelogue-a journey of discovery and self discovery and in part, an account of McGowan's experience of the ethnic conflict in Sri Lanka during the period of the Indo-Sri Lankan accord. McGowan, an American magazine journalist became interested in the ethnic conflict on his first visit to the Island in 1986 while in charge of an American college semester-abroad program. Sri Lanka and its ethnic conflict intrigued him so much that he went back in the fall of 1987.

The narrative style, more like that of a travelogue or novel, is a far cry from the usual dry academic tomes on the ethnic conflict. McGowan has combined an unusual mixture of literary skill and sensitivity. He uses the acute skills of observation of a reporter and an impressive knowledge of the literature on Sri Lanka in presenting this powerful book. The range of personal experiences he chronicles is also immense. They are as diverse and contradictory as his visit to a brothel, a Buddhist retreat in the jungle and dinner with two Generals in charge of the Indian offensive against the Tigers in Jaffna. He skillfully weaves these accounts of his personal experiences with historical insights to bring home the horror and tragedy of the ethnic conflict in Sri Lanka. His writing, with its Orientalist overtones in places, is unusually evocative. He writes of approaching to land in Sri Lanka:

The plane seemed to hang in the sky, without weight, without momentum ...The mists that rose from the jungle

Ravindiran Vaitheespara is currently working on his doctoral thesis in the History Department, University of Toronto. His recent paper, "Construction of a Geneology for Culture: TamilDravidian Consiousness and British Colonial Rule" will be published in Canadian Review of Studies in Nationalism. made the scene look creational...My dread grew more pronounced as the jungle became more articulated below us...It had a raw and visceral look to it now, the pulpiness of freshly wounded flesh. (:15)

Despite his penchant for metaphors and a mystical streak, his observations can also be very down to earth and incisive. Writing of his visit to a small town hospital to see one of his poorer Sri Lankan friend, Bonasuriya, who had been attacked by his neighbour with a machete over a fence dispute, he writes:

The hospital ward like most in Sri Lanka, was open to the air. Dogs prowled between the beds, licking the nights meal from the dishes of those who weren't quick enough to shoo them away ... Many of the other patients were also victims of violence. The man next to Bonasuriya had been set on fire by his own son, and was also lacking an ear from a similar fracas years before. (:202)

McGowan's analysis and description of Sri Lankans and the ethnic conflict seems to draw heavily from the literature on Sri Lanka, both old and new. In this regard, he seems to have done his homework rather well. One can see the influence of writers as diverse as Robert Knox, Anagarika Dharmapala, Walpola Rahula, Stanley Tambiah, Richard Gombrich, James Manor and Jonathan Spencer. Much of what he has to say about the origins of the ethnic conflict or of Sinhala-Buddhist revivalism is not new. However, what makes this book remarkable is that he illustrates the truths of what many of these writers have to say through accounts of his personal experience. It is this potent blend of the subjective and the anecdotal with the historical and the sociological that makes this book unique and powerful.

Refuge, Vol. 13, No. 3 (June 1993) 
Like many of the recent scholars that he draws from, McGowan blames the ethnic conflict on the wave of Sinhala Buddhistnationalism thatinitially swept the country in the late fifties. Like Gombrich, he argues that this form of Sinhala Buddhist revivalism-which Gombrich calls'protestant Buddhism'is a far cry from the more eclectic and syncretisticvariety that existed traditionally. He sees Tamil nationalism and the demand for a separate state largely as a defensive nationalism on the part of a minority, whose more moderate elites lost out to extremists as a result of their. powerlessness in the face of increasing state discrimination. He has a more nuanced understanding of the rise of Sinhala Buddhistnationalism, especially the post-1971JVPvariety-seen by some as part of the trajectory of the decolonization process; a reaction against the colonial and Christian missionary impact and the rule of corruption of the anglicized and westernized "Black English men." His own views of its rise seems to be close to that of a westernized Tamil he quotes in the book, "the road to hell can be paved with incredibly good intentions" (:158). This problem, essentially one of how to deal with this kind of reactive cultural nationalism, which of course is not unique to Sri Lanka, is not pursued seriously in his book. How does one deal with the rising discontent in the more secular but increasingly marginalized westernized ruling classes in many of the Third World countries which have often taken the form of a narrow and intolerant cultural nationalism of the majority community? The case of Iran and, more recently, India, has the academic community-drawn largely from this westernized class-totally perplexed. Should the ideal be a HongKong or a Singapore or a reassertion of a more eclectic vision of indigenous culture than the ones handed down by people such as Anagarika Dharmapala or Arumuga Navalar? The problem seems to lie with the uncritical anti-Westernism and uncritical culturaljingoism of much of these reactive cultural nationalist movements.

The accounts of his many encounters with the participants of the conflict is the unique feature of the book. Recounting a conversation with a bishop in Batticaloa, who was acting as a mediator between the Tamils and the Indian army there, he writes:

The core of the problem, the Bishop explained, was that the Indians were frustrated. 'In my opinion they do not understand terrorism properly. You can never put them down...Seven and eight year old boys can do it. Yes they are that young now. And girls too... True, there are those in the towns with ambition who want the war to end so they can get on with their own lives. But those in the villages whose lives are dull, they can easily be led into this. And the Tigers are their own flesh and blood. Do not ever forget that. That is the key factor-the emotional identification.' (:236)

In another episode, just after McGowan is prevented from proceeding further to Jaffna by the Indians at a road block near Vavuniya, and having been given an Indian captain as an escort back to the nearest town, he writes:

It was the unhappy task of a young Indian captain to wait with me for the public bus. As we sat on a log at the side of a dusty, untravelled road, the captain proved he was a philosophical sort, with the Hindu knack for cosmic irony and the grand sweep of time. "It is like the way you Americans went into Vietnam after the French had already lost. History tells it is a lost cause....What are we in this bloody country for anyway? These Tigers are trained killers and we will never win. The Buddhists are to blame. They have turned these Tamils into killers, and we are their dupes for coming to the rescue. (:311)

It is McGowan's knack for story telling that brings the ugliness and horror of the war home more vividly than any of the usual works on the subject. In one of the most surrealistic scenes in the book, where, McGowan, along with another American journalist is coaxed to have dinner with two Indian Generals in charge of the Indian offensive against Jaffna, we get McGowan at his best:

When we arrived back at Gnaniam's from the day's rounds, there was a jeep and an armed escort of two soldiers waiting for us. There was no begging off the banquet. 'You need not be wor- ried about anything,' one of the generals assured me over the phone. 'We can promise you that there will be no problem. Our troops are well trained and disciplined and will make sure there will be no incidents.'

This scene in the heart of Jaffna takes on a surreal quality, given that it was happening in the midst of fierce fighting between the Indians and the Tigers in Jaffna. McGowan continues:

Initially the Brigadiers reminded me of two college frat boys. Brigadier Kahlon complained about his weight, and said that since he only played golf, there was no way for him to get any exercise, as Jaffna lacked a golf course ... The scotch loosened their tongues ... Kahlon continued ... He had been shocked when he realized just how deep the breach had grown between the two communities. The prior autumn, he had seen the aftermath when Sinhalese helicopter pilots fired on Tamil civilians trying to flee the Jaffna peninsula. 'They are filled with hate toward them, pure hate,' Kahlon said in disgust. 'How could they fly out to that ferry, hover twenty feet over the heads of people below, while the people held out their babies so they see they were not militants, and fire directly on them? The sea turned completely red, bloody pure red. I saw it with my own eyes ... In the generals estimation, the Research and Analysis Wing had screwed up in backing the other rebel groups and trying to cut the Tigers out of the equation for power sharing.' (:327-329)

When Catherine Manegold, the other journalist with McGowan, asked the generals about allegations of rape by Indian soldiers in Jaffna, the reply of general Magid Singh, according to McGowan was:

'Four rapes, forty, four hundred. How can we ever tell how many? It is so very hard to say,' said Singh. 'Anyway you don't have to worry about us. We are Sikhs and we like our women fair.'(:329)

The book is full of such accounts. It is such candid glimpses of many of the participants of the war that makes this book especially valuable.

On the negative side, the book suffers from a lack of in-depth analysis of the 
Tamils and their political behaviour in Sri Lanka. By focusing largely on the Sinhalese, McGowan is not as critical of the Tamils, nor does he address the complexities of Tamil society and political behaviour in Sri Lanka. In a way, this shortcoming reflects the relative paucity of scholarly works on contemporary Tamil society in Sri Lanka. There are also a few factual and spelling errors of names. For example, he spells Velupillai Prabaharan as Vellupai Prabakeran and talks of the Buddhist emperor, Asoka as a South Indian Buddhist King. The book's focus is largely on a culturalist understanding of the Sri Lankans and the ethnic conflict. A little more emphasis on socio-economic factors would have been more balanced. The lack of footnotes and bibliography is also a significant shortcoming. Apart from these limitations, I would recommend this book to any student of Sri Lanka, especially to those who have had an overdose of dry academic discourses on the subject. $\mathbf{w}$

\section{The Refugee Crisis in Russia \\ by Professor Rozalina Ryvkina and Dr. Rostislav Turovskiy (Russia) \\ Edited with an Introduction by Professor Robert J. Brym (University of Toronto, Canada) \\ Published by York Lanes Press for the Centre for Refugee Studies, York University. \\ ISBN 1-55014-000-0 • Price: \$9.95 \\ This is a study of the number of refugees in Russia, their geographical and ethnic composition, the causes of the refugee problem, relations between refugees and populations in areas of resettlement, state refugee policy, forecasts of refugee trends and possible means of ameliorat- ing the refugee crisis. \\ To order your copy, please contact: \\ York Lanes Press, \\ Suite 351 York Lanes \\ York University \\ 4700 Keele Street \\ North York, Ontario \\ Canada M3J 1P3 \\ Fax: (416) 736-5837}

\begin{tabular}{|c|c|c|c|c|c|c|c|}
\hline \multicolumn{8}{|c|}{$\begin{array}{l}\text { Convention Refugee Determination Hearings } \\
\text { January } 1 \text { - March 31, } 1993\end{array}$} \\
\hline \multicolumn{8}{|c|}{ Regional Summary } \\
\hline & & Atlantic & Quebec & Ontario & Prairies & B.C. $\mathrm{I}$ & National \\
\hline & Claims heard & 128 & 2,274 & 3,524 & 132 & 289 & 6,347 \\
\hline & Decisions rendered & 125 & 2,281 & 3,212 & 155 & 340 & 6,131 \\
\hline & Claims rejected & 48 & 1,015 & 1,303 & 72 & 240 & 2,678 \\
\hline & Claims upheld & 77 & 1,266 & 1,909 & 83 & 100 & 3,453 \\
\hline & Withdrawn/abandoned & 4 & 174 & 472 & 5 & 30 & 685 \\
\hline & Decisions pending * & 65 & 740 & 1,834 & 18 & 144 & 2,801 \\
\hline & Claims pending ** & 168 & 7,369 & 13,116 & 209 & 1,461 & 22,323 \\
\hline \multicolumn{8}{|c|}{$\begin{array}{l}\text { \# Claims heard to completion; includes cases heard before } 1993 . \\
\text { "Decisions pending include all claims heard to completion for which no decision had been } \\
\text { rendered by the end of the reporting period. } \\
\text { * Claims pending include all claims referred to the Convention Refugee Determination } \\
\text { Division that have not been finalized (i.e. by a positive or negative decision or by } \\
\text { withdrawal or abandonment) as of the end of the reporting period. }\end{array}$} \\
\hline \multicolumn{8}{|c|}{ Statistical Summary by Major Source Countries } \\
\hline \multirow{2}{*}{\multicolumn{2}{|c|}{$\begin{array}{l}\text { Source } \\
\text { Country }\end{array}$}} & \multicolumn{2}{|c|}{ Claims } & \multicolumn{2}{|c|}{$\begin{array}{l}\text { Convention } \\
\text { Refugee Status }\end{array}$} & \multirow{2}{*}{$\begin{array}{l}\text { Claims } \\
\text { Decided }\end{array}$} & \multirow{2}{*}{$\begin{array}{c}\% \\
\text { Accept. }\end{array}$} \\
\hline & & Completion & Abandoned & Yes & No & & \\
\hline 1 & Sri Lanka & 1,101 & 37 & 849 & 168 & 1,017 & 83.5 \\
\hline 2 & Somalia & 800 & 27 & 783 & 35 & 818 & 95.7 \\
\hline 3 & Pakistan & 292 & 30 & 80 & 159 & 239 & 33.5 \\
\hline 4 & China & 274 & 27 & 42 & 259 & 301 & 14.0 \\
\hline 5 & Iran & 241 & 16 & 157 & 79 & 236 & 66.5 \\
\hline 6 & Lebanon & 236 & 31 & 77 & 144 & 221 & 34.8 \\
\hline 7 & India & 213 & 29 & 50 & 127 & 177 & 28.2 \\
\hline 8 & El Salvador & 179 & 35 & 41 & 173 & 214 & 19.2 \\
\hline 9 & Guatemala & 154 & 32 & 97 & 89 & 186 & 52.2 \\
\hline 10 & Russia & 148 & 10 & 84 & 47 & 131 & 64.1 \\
\hline 11 & Haiti & 147 & 5 & 84 & 52 & 136 & 61.8 \\
\hline 12 & Romania & 138 & 3 & 71 & 55 & 126 & 56.3 \\
\hline 13 & Ghana & 137 & 68 & 20 & 109 & 129 & 15.5 \\
\hline 14 & Peru & 128 & 5 & 90 & 32 & 122 & 73.8 \\
\hline 15 & USSR & 110 & 23 & 44 & 96 & 140 & 31.4 \\
\hline 16 & Nigeria & 108 & 16 & 12 & 66 & 78 & 15.4 \\
\hline 17 & Zaire & 107 & 3 & 67 & 65 & 132 & 50.8 \\
\hline 18 & Bangladesh & 106 & 15 & 32 & 60 & 92 & 34.8 \\
\hline 19 & Israel & 106 & 17 & 25 & 69 & 94 & 26.6 \\
\hline 20 & Sudan & 92 & 2 & 87 & 9 & 96 & 90.6 \\
\hline 21 & Ukraine & 86 & 6 & 43 & 23 & 66 & 65.2 \\
\hline 22 & Uruguay & 85 & 16 & 5 & 79 & 84 & 6.0 \\
\hline 23 & Cuba & 71 & 4 & 59 & 20 & 79 & 74.7 \\
\hline 24 & Argentina & 67 & 30 & 13 & 56 & 69 & 18.8 \\
\hline \multirow[t]{4}{*}{25} & Ethiopia & 63 & 3 & 46 & 23 & 69 & 66.7 \\
\hline & Top-25 countries total & 5,189 & 490 & 2,958 & 2,094 & 5,052 & 58.6 \\
\hline & Total Claims & 6,347 & 685 & 3,435 & 2,678 & 6,113 & 56.2 \\
\hline & \multicolumn{7}{|c|}{ Source: Immigration and Refugee Board News Release, May 28, 1993} \\
\hline
\end{tabular}

Refuge, Vol. 13, No. 3 (June 1993) 


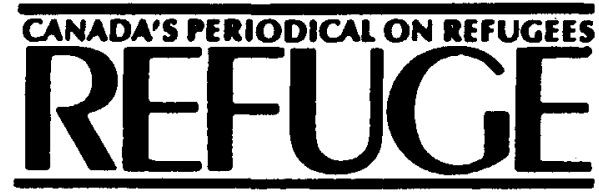

Refuge

York Lanes Press

Centre for Refugee Studies Suite 351, York Lanes, York University

4700 Keele Street, North York

Ontario, Canada M3J 1P3

Phone: (416) 736-5843 - Fax: (416) 736-5837

Electronic Mail via Bitnet Address:

REFUGE @YORKVMI

Postage Paid in Toronto, Canada

Second Class Mail Registration No. 5512

Return Postage Guaranteed

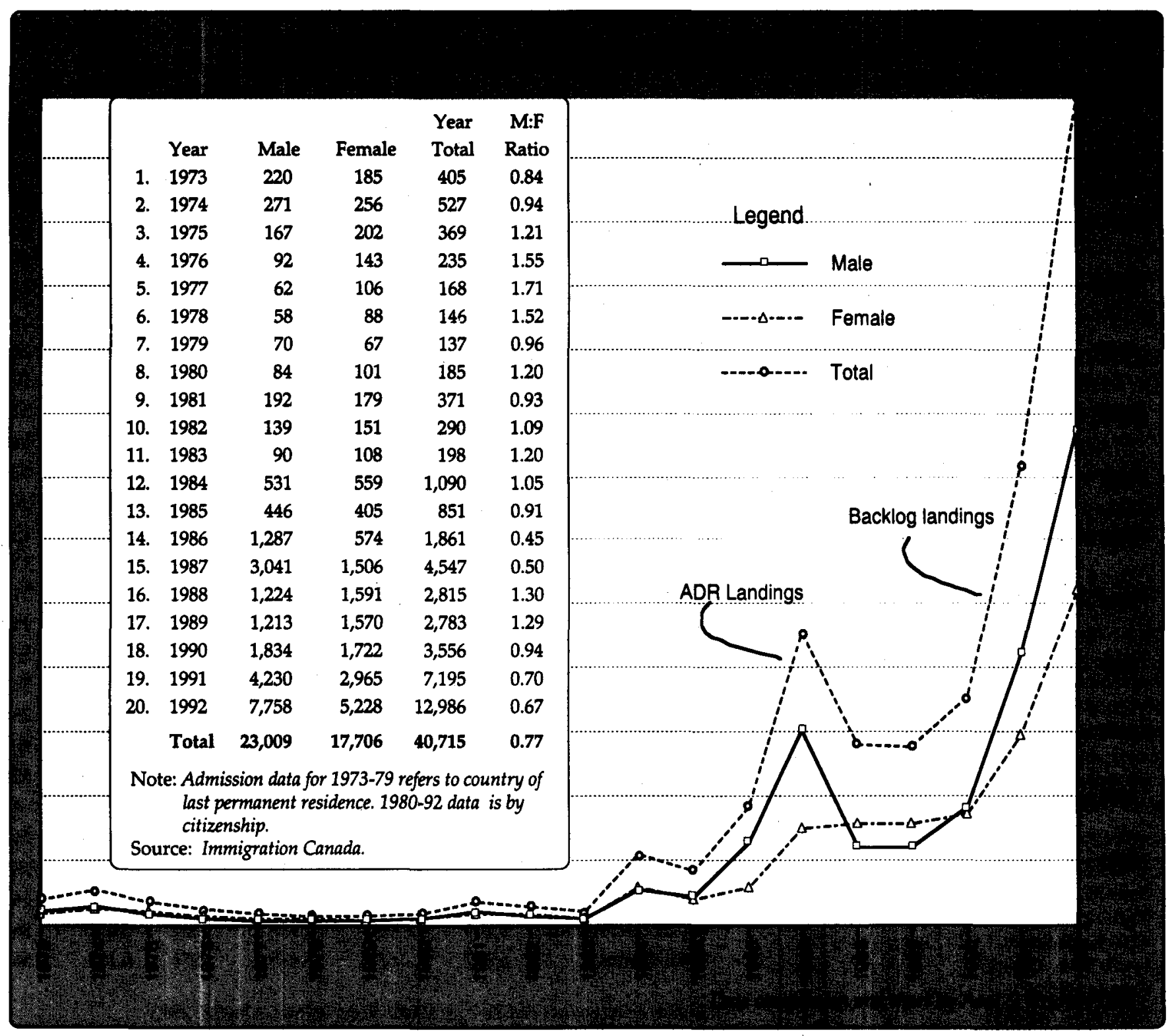

